\title{
SEROPREVALENCE OF BRUCELLA ABORTUS ANTIBODIES IN THE CATTLE POPULATION IN THE SELECTED UPAZILAS OF SIRAJGONJ DISTRICT
}

\author{
S. M. S. H. Belal ${ }^{1 *}$ and A. R. M. I. H. Ansari ${ }^{2}$ \\ ${ }^{1}$ Veterinary Surgeon, District Veterinary Hospital, Sirajgonj \\ ${ }^{2}$ Veterinary Surgeon, District Veterinary Hospital, Nilphamary
}

\begin{abstract}
A study was carried out on 135 commercial dairy farms of five upazillas of Sirajgonj district to know the prevalence of Brucella abortus antibody in herds during the period from January 2012 to December 2013. A total of 270 blood samples were tested by Anigen ${ }^{\circledR}$ Rapid Brucella Ab test kit. The overall prevalence of bovine brucellosis was recorded as $8.51 \%$. Distribution on the basis of breed, age, sex and pregnancy revealed the significant relationship among the infection, breed, sex, age and pregnancy in the population. The prevalence was relatively high in older cattle $(9.09 \%)$ and the highest prevalence was $9.34 \%$ in the pregnant female. The prevalence of Brucella abortus antibody was considerably high in most of the large herds. Further study is needed to know the species and biovar of Brucella circulating in the study area.
\end{abstract}

Key words: Brucellosis, cattle, seroprevalence, Anigen ${ }^{\circledR}$ Test Kit

\section{INTRODUCTION}

Livestock industry plays an important role in the economy of the country. Human life is highly associated with livestock population in the different livestock production systems (Bekele et al., 2010). But the sector is continuously facing some threats; brucellosis is one of them which not only affect the cattle population but also human associated with it. In both pastoral and mixed livestock production systems, people live very closely with livestock having a high incidence of brucellosis and thus, are at higher risk of acquiring the infection (Gebretsadik et al., 2007). Brucellosis is a disease of domestic, livestock and wild animals with serious zoonotic implications in man; causing huge economic losses to the livestock industry. Cattle, goats, pigs, sheep, horses and dogs play an important role in the transmission of this disease to man. It is defined as a contagious systemic bacterial disease primarily of ruminants, characterized by inflammation of the genital organs and fetal membranes, abortion, sterility and formation of localized lesions in the lymphatic system and joints (WHO, 1971; CDC, 2005). Brucellosis is a zoonosis transmitted directly or indirectly by exposure to infected animals (Mandell et al., 2005). It is considered as one of the most important zoonoses in the world (WHO/FAO/OIE, 2004). Although the density of cattle population is high in Sirajgonj but most of the previous studies on bovine brucellosis have been carried out nationally, and do not provide an adequate epidemiological picture of the disease in this zone. We, therefore, designed a study to know the seroprevalence of brucellosis in cattle as measured by the Antigen rapid Brucella Ab test kit.

\section{MATERIALS AND METHODS}

Location and duration of study

Five Upazillas of Sirajgonj district namely Sirajgonj Sadar, Shahjadpur, Ullapara, Kamarkhand and Belkuchi were selected on the basis of number and size the herds. Three administrative union from each Upazilla and three villages from each union were taken for this study. The study was conducted over a period of 24 months during January 2012 to December 2013.

\section{Animal selection and sample collection}

Three herds from each village and two cattle of over 6 months old from each herd were selected for the study. About $10 \mathrm{ml}$ of whole blood sample was collected from the jugular vein, using plain vaccutainer tubes and needles from each cattle aged above six and with no history of vaccination for brucellosis. Each sample tube was labeled using codes specific to the individual sample. The tubes were tilted and serum was collected either passively by decanting or after centrifugation of the blood samples at 2,500 rpm for $5 \mathrm{~min}$. The serum was stored at $-20^{\circ} \mathrm{C}$ until tested serologically.

\section{Rapid kit test (Chromatographic Immunoassay)}

The samples were subjected to Anigen ${ }^{\circledR}$ Rapid B. Brucella Antibody Test Kit for the detection of Brucella abortus antibodies.

\footnotetext{
*Corresponding e-mail address: shariful.belal@yahoo.com 


\section{S. M. S. H. Belal and A. R. M. I. H. Ansar}

As, for the interpretation of test results, positive reactions were indicated by the appearance of two distinct red lines (Figure 1), the chances of misinterpretation were little or absence.

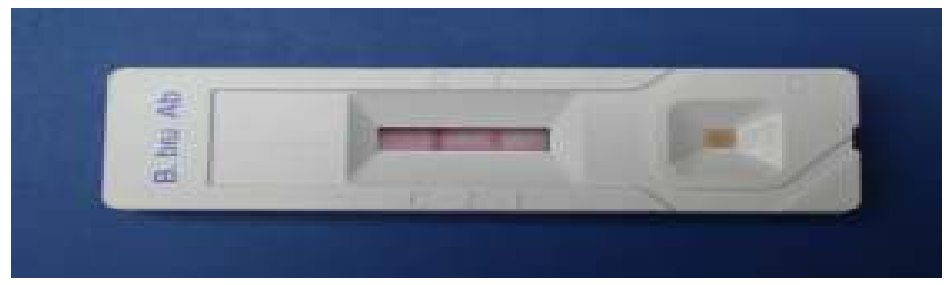

Figure 1: Positive result

\section{RESULTS AND DISCUSSION}

Over the study period, although an average seroprevalence of $8.51 \%$ was obtained, but the prevalence was found to vary insignificantly in different upazillas. The highest prevalence was found in Shahjadpur upazila $(11.11 \%)$ and the lowest was found in Belkuchi (5.55\%) (Table 1). Although some studies reported variable trend in the prevalence of the disease (Rahman et al., 2012; Rahman et al., 2013) but the prevalence obtained in this study represent area of high cattle density where there are chances of intermixing during free grazing in the field (bathan) during dry season. The farmers of this area were accustomed to an extensive system of management, keeping both healthy and infected animals together under purely traditional systems and providing less nutritious feed which made animals highly susceptible to diseases like brucellosis and tuberculosis (Adesokan et al., 2006).

Table 1. Distribution of brucellosis in cattle in different areas of Sirajganj district

\begin{tabular}{|ccccc|}
\hline Upazilla & $\begin{array}{c}\text { Number of } \\
\text { Union }\end{array}$ & Tested & Positive & Prevalence \\
\hline Sirajgonj Sadar & 03 & 54 & 05 & $9.25 \%$ \\
Shahjadpur & 03 & 54 & 06 & $11.11 \%$ \\
Ullapara & 03 & 54 & 05 & $9.25 \%$ \\
Kamarkhand & 03 & 54 & 04 & $7.40 \%$ \\
Belkuchi & 03 & 54 & 03 & $5.55 \%$ \\
\hline Overall & 15 & 270 & 23 & $8.51 \%$ \\
\hline
\end{tabular}

Table 2.Age-wis Prevalence of brucellosis in cattle

\begin{tabular}{|cccc|}
\hline Age group & Tested & positive & Prevalence \\
\hline 6 month-2 yr. & 74 & 6 & 8.11 \\
>2-6 yrs. & 108 & 9 & 8.33 \\
Above 6 yrs. & 88 & 8 & 9.09 \\
\hline Overall & 270 & 23 & 8.51 \\
\hline
\end{tabular}

Prevalence of bovine brucellosis found in the study area was $8.11 \%$ in the younger stock which was increasing with the advance of age and reached as much as $9.09 \%$ in animals older than 6 years (Table 2). Animals younger than 6 months were not included in this study because of lacking report of occurrence in this age group. Adult cattle over the age of 3 years had the highest seroprevalence. Younger animals are said to be less susceptible to B. abortus than older. Sexually mature animals and non-vaccinated young cattle are at higher risk of brucellosis if exposed to pathogenic strains of the organism (Radostits et al., 1995). Variation in the seroprevalence was also observed with sex. Female maintained a comparatively higher seroprevalence than the male. The prevalence of brucellosis, regardless of the upazilla, in male and female was $7.60 \%$ and $8.97 \%$ respectively and among the female, pregnant female was found carrying highest rate of seroprevalence and it was $9.34 \%$ (Table 3 ).

The prevalence of brucellosis was relatively higher in Holstein-Friesian $\times$ Local cross-breed $(8.75 \%)($ Table 4). Similar reports were also made by others (Cadmus et al., 2006; Cadmus et al., 2008) and the Holstein Friesian cross with indigenous cattle is the most predominant breed in the study area. 
Table 3.Prevalence of brucellosis on the basis of sex of cattle

\begin{tabular}{|cccc|}
\hline Sex & No. of sample & Positive & Prevalence \\
\hline Male & 105 & 8 & 7.60 \\
Female & 58 & 5 & 8.61 \\
Pregnant female & 107 & 10 & 9.34 \\
\hline Total & 270 & 23 & 8.51 \\
\hline
\end{tabular}

Table 4. Prevalence of brucellosis on the basis of breed of cattle

\begin{tabular}{|cccc|}
\hline Breed & No. of sample & Positive & Prevalence \\
Local & 60 & 5 & 8.34 \\
$\mathrm{HF} \times \mathrm{L}$ & 80 & 7 & 8.75 \\
$\mathrm{SL} \times \mathrm{L}$ & 70 & 6 & 8.58 \\
$\mathrm{~S} \times \mathrm{L}$ & 60 & 5 & 8.34 \\
\hline Overall & 270 & 23 & 8.51 \\
\hline
\end{tabular}

Local=Indigenous cattle, $\mathrm{HF}=$ Holstein-Friesian, $\mathrm{SL}=$ Sahiwal, $\mathrm{S}=$ Sindhi, $\mathrm{L}=$ Local cattle

The male to female infection ratios recorded over the years where females were found more susceptible to brucellosis (Table 3). This may be due to the inclusion of more pregnant cows in the population studied as the sexually mature pregnant cattle are more susceptible to infection than sexually immature cattle of either sex (Radostits et al., 1995).

Brucellosis is a worldwide zoonosis (Nicoletti et al., 1993) that causes serious economic losses in livestock and poses important human health hazards worldwide (Ibrahim et al., 2010). One of the major implications of the burden of this disease is the exposure of livestock traders, butchers and other meat processors as well as veterinarians/meat inspectors. The poor facilities and safety precautions in most herds and slaughter houses contribute to the likelihood of exposure. In most instances, these personnel use their bare hands to handle infected organs and carcasses from diseased animals.

The economic impact and public health significance of the uncontrolled prevalence of brucellosis in livestock population is undoubtedly high (Cadmus et al., 2008) and the financial costs of the disease nationally has to be been estimated (Ajogi et al., 1998, 2001).

In conclusion, therefore, for the control and eradication of brucellosis in cattle population, more attention should be paid towards separation of healthy and infected animals/herds. This should be combined with more government intervention in the areas of regulations and policies concerning routine screening of all cattle populations, purchasing healthy bulls from foreign market, using semen from healthy bull for artificial insemination, introduction of vaccine in herd where the prevalence is very high, etc. Awareness program should be undertaken involving stakeholders in the livestock industry as well as consumers to avert public health and economic losses associated with brucellosis.

\section{ACKNOWLEDGEMENTS}

The authors are very thankful to Dr. M. Rafiqul Islam, Associate Professor, Department of Anatomy and Histology, BAU, Mymensingh for editing the manuscript. The authors are grateful to Md. Mazharul Alam Akanda, DLO, Sirajgonj for permitting VFA (Veterinary field Assistant) to collect blood samples.

\section{REFERENCES}

1. Adesokan HK, Ijagbone IF, Oputa HE, Cadmus SIB Stack JA (2006). Serological survey of brucellosis in livestock animals and workers in Ibadan, southwestern, Nigeria. African Journal of Biomedical Research 9:163-168.

2. Ajogi I, Akinwunmi JA (2001).Cash-flow model of the cost of brucellosis in traditionally managed cattle herds in Nigeria. Bulletin of Animal Health and Production in Africa 49:169-173. 


\section{S. M. S. H. Belal and A. R. M. I. H. Ansari}

3. Ajogi I, Akinwunmi JA, Esuruoso GO, Lamorde G (1998).Settling the nomads in Wase-Zange grazing reserves in the Sudan Savannah zone of Nigeria. III. Estimated financial losses due to bovine brucellosis. Nigerian Veterinary Journal 19:86-94.

4. Asmare K, Prassad S, Asfaw Y, Gelaye E, Ayelet G, Zeleke A(2007).Seroprevalence of brucellosis in cattle and high risk animal health professionals in Sidama Zone, Southern. Ethiopian Veterinary Journal11:69-84.

5. Bekele B. Demelash A. Fufa A. Regassa J. Godfroid, and Skjerve E (2010). Seroprevalence of brucellosis and its contribution to abortion in cattle, camel, and goat kept under pastoral management in Borana, Tropical Animal Health and Production 43: 651-656.

6. Berhe G, Belihu K, Asfaw Y (2007). Seroepidemiological investigation of bovine brucellosis in extensive cattle production system of Tigray region of Ethiopia. International Journal of Applied Research in Veterinary Medicine 5:65-71.

7. Cadmus SIB, Ijagbone IF, Oputa HE, Adesokan HK \& Stack JA(2006).Serological survey of brucellosis in livestock animals and workers in Ibadan, Nigeria. African Journal of Biomedical Research 9, 163-168.

8. Crawford RP, Huber JD, Adams BS (1990). Epidemiology and Surveillance in Animal brucellosis. Edited by Nielsen K, Duncan JR. CRC Press Inc., Florida 131-148.

9. Cadmus SIB, Adesokan HK, Stack J (2008). The use of the milk ring test and Rose Bengal test in brucellosis control and eradication in Nigeria. Journal of the South African Veterinary Association 79:113-115

10. Gebretsadik B, Kelay, Yilkal A (2007).Seroepidemiological investigation of bovine brucellosis in the extensive cattle production system of Tigray region of Ethiopia. International Journal of Applied Research in Veterinary Medicine 5 (2): 65-71.

11. Hailemelekot M, Kassa T, Tefera M, Belihu K, Asfaw Y, Ali A (2007). Seroprevalence of brucellosis in cattle and occupationally related humans in selected sites of Ethiopia. Ethiopian Veterinary Journal11:85100 .

12. Ibrahim N, Belihu K, Lobago F, Bekana M (2010). Seroprevalence of bovine brucellosis and its risk factors in Jimma zone of Oromia region, South-western Ethiopia. Tropical Animal Health and Production42:35-40.

13. Ishola OO,Ogundipe GAT (2000).Seroprevalence of brucellosis in trade cattle slaughtered in Ibadan, Nigeria. Bulletin of Animal Health and Production in Africa 48:53-55

14. Mandell GL, Dolin R (eds.) \& Bennett JE, (2005). Principles and Practice of Infectious Diseases, 6th edn.pp. 2386-2391, Churchill Livingstone, New York.

15. MinjaKSG (2002).Sero-epidemiological survey of Brucella antibodies in indigenous cattle and human occupational groups in Babati and Hanang districts, MVM thesis, Department of Veterinary Medicine and Public Health, Sokoine University of Agriculture.

16. Nicoletti P, Howard JL (ed.), Saunders WB (1993). Brucellosis. In: Current veterinary therapy. Food animal practice (3rd edn) Philadelphia: 551-555.

17. Oputa HE, Ijagbone IF, Adesokan HK, Stack JA (2006).A survey of brucellosis in animals and animal workers. African Journal of Biomedical Research 9:163-168

18. Ocholi RA, Kwaga JKP, Ajogi I, Bale JOO (2004). Phenotypic characterization of Brucella strains isolated from livestock in Nigeria. Veterinary Microbiology 103:47-53.

19. Radostits OM, Blood DC, Gay CC (1995). Veterinary medicine - A textbook of the diseases of cattle, sheep, pigs and horses (8th edn). Baillière Tindall, London.

20. Rahman, AKMA, Saegerman C., Berkvens D, Fretin D, Gani MO, Ershaduzzaman M, Ahmed MU and Emmanuel A (2013): Bayesian estimation of true prevalence, sensitivity and specificity of indirect ELISA, Rose Bengal Test and Slow Agglutination Test for the diagnosis of brucellosis in sheep and goats in Bangladesh. Preventive Veterinary Medicine 110: 242-252.

21. Schoonman L.(2007).Epidemiology of leptospirosis and other zoonotic diseases in cattle in Tanzania and their relative risk to public health, PhD thesis, Department of Veterinary Medicine and Public Health, University of Reading.

22. Swai ES \& Schoonman L (2009).Human brucellosis: Seroprevalence and risk factors related to high risk occupational groups in Tanga Municipality, Tanzania, Zoonoses and Public Health 56, 183-187.

23. World Health Organization, Food and Agriculture Organization of the United Nations \& World Organization for Animal Health (2004).Report of the WHO/FAO/OIE joint consultation on emerging zoonotic diseases, World Health Organization, Geneva. 